\title{
'n Praktiese riglyn vir die gebruik van die Louw \& Nida-Woordeboek
}

\author{
Geillustreer aan die hand van die betekenis van \\ каıрó $\zeta$ in Galasiërs $6: 9$ - 10' \\ Jan Botha, Dept Grieks, $\mathrm{PU}$ vir $\mathrm{CHO}$
}

\section{ABSTRACT}

Practical guidelines in the use of the Louw \& Nida Dictionary The Greek-English lexicon of the New Testament based on semantic domains, (2 vols), compiled by JP Louw \& EA Nida, is unique in many respects. Its most important feature, however, is the fact that the material in the Lexicon is arranged and presented in semantic domains and not alphabetically. Because of this significant and important difference with traditional lexicons, it might initially be a problem to find an adequate method to gain the optimum value from the practical use of the Lexicon. The guideline is illustrated by means of a discussion of the meaning of кaıpos in $\mathrm{Gal} 6: 9-10$.

\section{INLEIDING}

In plaas daarvan om 'n alfabetiese lys van Griekse woorde te gee met moontlike "vertaalekwivalente" daarnaas, is die woorde van die Nuwe Testament in die Louw \& Nida-woordeboek in semantiese velde gerangskik (Louw \& Nida $1988 \mathrm{I}$ : vi). Hierdie ordeningsbeginsel is waarskynlik die mees uitstaande kenmerk van die woordeboek. Dit maak die woordeboek uniek en ook uiters waardevol vir elkeen wat hom- of haarself besig hou met die interpretasie van die Nuwe Testament.

As gevolg van hierdie ingrypende verskil met tradisionele woordeboeke, mag dit moontlik vir 'n nuwe gebruiker aanvanklik ' $n$ probleem wees om 'n praktiese metode te vind om die woordeboek optimaal te kan benut. In die eerste plek is dit nodig om jouself op hoogte te stel van die vernaamste teoretiese beginsels waarop die woordeboek berus. Maar selfs mét sodanige teoretiese agtergrond, mag dit nog steeds 'n probleem wees om te weet hoe om doelgerig te werk te gaan om die meeste uit die woordeboek te kan put.

Die doel van hierdie artikel is om teen die agtergrond van die teoretiese sake wat in 'n vorige artikel behandel is, 'n praktiese riglyn voor te stel vir die gebruik van die woordeboek. Die riglyn word geillustreer aan die hand van die betekenis van кaıpós in Galasiërs $6: 9-10$.

Soos met enige eksegetiese voorstel wat die proses in meganiese "stappe" probeer opbreek, het ook hierdie riglyn ernstige leemtes. Ter wille van die didaktiese gerigtheid daarvan is ' $n$ mens genoodsaak om die proses in eenvoudige en chronologies opeenvolgende stappe te

$$
24 \text { - In die Skriflig 1989, } 23 \text { (4) }
$$


probeer beskryf. In die praktyk is dit egter 'n baie meer organiese proses. Daarom word dit ook as 'n riglyn bestempel en pretendeer dit nie om 'n perfekte metode te wees wat meganies toegepas kan word om gewaarborgde resultate te verkry nie (vergelyk verder oor hierdie tipe problematiek, Deist, 1988). Die taal en die eksegese van geskrewe tekste is dinamiese groothede wat hulle eenvoudig nie in sulke kliniese meganika laat indwing nie. Dit doen nie afbreuk aan die eis dat 'n mens so ver moontlik sistematies en verantwoord te werk moet gaan nie. Daartoe wil hierdie artikel graag 'n bydrae lewer.

In die inleiding van die woordeboek bespreek die samestellers drie basiese benaderingswyses in die gebruik daarvan: (i) beginnende met 'n Griekse woord, (ii) beginnende met 'n Engelse woord of (iii) beginnende met 'n spesifieke Skrifgedeelte (Louw \& Nida 1988: xi-xv). Hierdie drie benaderingswyses berus op die drie verskillende soorte indekse wat in Volume II aangegee word (vergelyk \$2.8 van vorige artikel). Hierdie artikel word grootiiks gerig op die bespreking van die Grieks-Engelse indeks. Na die behandeling daarvan word slegs enkele kort opmerkings oor die gebruik van die ander indekse gemaak. Die riglyne wat hier volg. berus in baie opsigte op die voorstelle van die samestellers - met dié verskil dat dit meer spesifiek didakties gerig is en die feit dat dit breedvoerig met een praktiese voorbeeld geillustreer word.

\section{AGT VOORGESTELDE STAPPE VIR DIE OPTIMALE BENUTTING VAN DIE WOORDEBOEK}

\subsection{Praktiese illustrasie van die toepassing van hierdie stappe aan die} hand van die betekenis van die woord кaıрó in Galasiërs $6: 9$ - 10

Vanwee die didaktiese gerigtheid van hierdie artikel, word hierdie illustrasie soos volg aangebied: elke stap word duidelik genommer en van 'n tiperende opskrif voorsien. Direk daarna word die opdrag ter uitvoering van die betrokke stap geformuleer (en tipografies gemerk deur dit binne 'n blokkie te plaas). Aan die einde van die behandeling van die stappe, word 'n sinopsis van al agt stappe gegee.

Gestel 'n mens is besig om 'n preek te maak met Galasiërs $6: 9-10$ as teksverse. ${ }^{2}$ Daar staan die volgende:

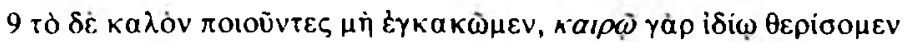

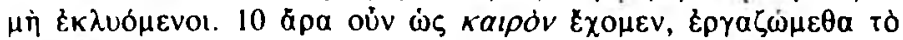

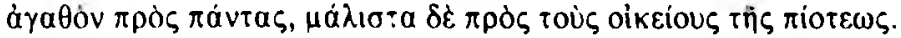

Laat ons dan nie moeg word om goed te doen nie, want op die bestemde tyd sal ons die oes insamel as ons nie verslap nie. Solank ons dus die geleentheid het, laat ons aan almal goed doen, veral aan die huisgenote van die geloof (Eie vertaling en kursiverings).

Dit is duidehk dat dit nodig is om die betekenis van die woord kaıpós in hierdie verse noukeurig vas te stel. Die woord word twee keer gebruik en beide Afrikaanse vertalings vertaal dit in vers 9 met "tyd" en in vers 10 met "geleentheid". 
Soek die Griekse woord in die indeks in Volume 2 op.

Die eerste stap is om die Griekse woord in Vol 2 van die Louw \& Nidawoordeboek na te slaan. Op p 128 in hierdie indeks vind ons die volgende inskrywing:
каıрós, oṽ $m$
a occasion
b period of time
c era
d opportunity
кaıpóc: units

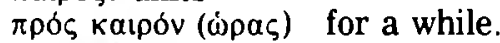

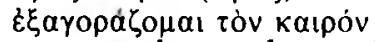
a make good use of opportunity.
b work urgently.

STAP 2 - Interpretasie van die gegewens van Volume 2

Interpreteer die gegewens wat die indeks bied, naamlik (i) in hoeveel en (ii) in watter semantiese velde die woord voorkom, en (iii) of $j y$ in hierdie spesifieke geval nie moontlik met 'n idiomatiese uitdrukking waarin die woord voorkom, te doen het nie.

Uit hierdie gegewens kan ons dle volgende aflei: die woord kaıpós word in die Nuwe Testament in twee verskillende semantiese velde gebruik,

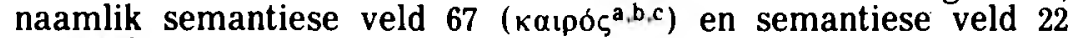
( $\kappa$ aıpó $\varsigma^{d}$ ). Binne semantiese veld $67 \mathrm{kom}$ die woord in drie verskillende

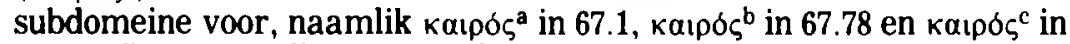
67.145. Saam met die voorsetsel $\pi \rho \delta \varsigma$ vorm кaı ó $\varsigma$ 'n vaste uitdrukking wat in semantiese veld 67 subdomein 109 voorkom en die idiomatiese

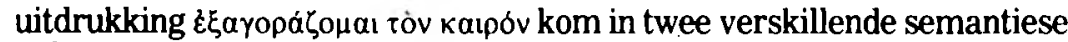
velde voor, naamlik 65 en $68 .^{3}$

Dit is belangrik om te onthou dat die woorde "occasion", "period of time", "era" en "opportunity" wat in die indeks aangegee word nie die verskillende betekenisse van kaıpó in die Nuwe Testament is nie, maar wel glosse of (Engelse!) vertaalmoontlikhede vir die verskillende betekenisse van die woord. Verder is die nommers 67.1, 67.78, 67.145 en 22.45 slegs ' $n$ gids om jou te lei na die regte plekke in Vol 1. Eers wanneer jy Volume 1 raadpleeg, kan jy vasstel wat die naam van semantiese velde 67 en 22 is en in watter subdomeine binne hierdie semantiese velde die verskillende betekenisse van кaıрó voorkom. Hoewel die GrieksEngelse indeks in Vol 2 op sigself dus baie waardevolle gegewens bied, is dit in die eerste plek 'n gids om 'n mens te lei na Vol 1.

STAP 3 - Fokus binne konteks

Besluit watter betekenismoontlikheid of betekenismoontlikhede die waarskynlikste van toepassing is in die konteks wat bestudeer word. 
In die geval van die betekenis(se) van kaıpós in Galasiërs $6: 9-10$, is

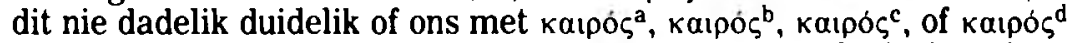
te doen het nie. Dit sal dus nodig wees om al vier hierdie inskrywings na te gaan.

\section{STAP 4 - Raadpleging van Volume 1}

Soek die betrokke verwysing na die toepaslike semantiese veld en subdomein waarop in stap 3 besluit is, in Vol 1 van die woordeboek op.

Die semantiese velde in Vol 1 is duidelik bo-aan elke bladsy aangedui. Om semantiese velde 67.1, 67.78, 67.145 en 22.45 in Vol 1 op te soek, is dus maklik en 'n mens kan direk daarheen blaai.

\section{STAP 5 - Semantiese woordsoort}

Plaas die semantiese veld binne die geheelkonteks van die semantiese velde soos wat dit in Vol 1 geklassifiseer is.

By die uitvoering van hierdie stap word dit reeds duidelik watter groot

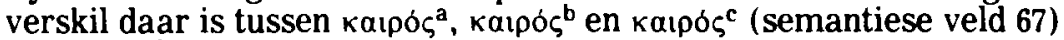
en kaıpó $\varsigma^{d}$ (semantiese veld 22 ): semantiese veld 67 val onder die semantiese woordsoort abstrakte en semantiese veld 22 val onder die semantiese woordsoort gebeure. Hierdie inligting moet ons nou van toepassing maak op die interpretasie van kaıpós in ons teksverse. Dit lyk asof kaipos in vers 10 'n gebeure-woord is, want dit dui op 'n toestand.

Ons kan кaıрòv Ě $о \mu \varepsilon v$ getransformeerd vertaal met: "ons is in omstandighede". (Letterlik vertaal is dit: "ons het tyd" of "ons het geleent-

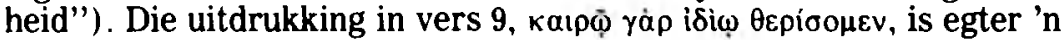
abstrak, want dit kwalifiseer die gebeurewoord $\theta \varepsilon \rho i \sigma o \mu \varepsilon v$ nader ten opsigte van tyd: "ons sal insamel op die bestemde tyd".

Deur die toepassing van hierdie stap het ons dus reeds 'n goeie ent vordering gemaak om die twee betekenismoontlikhede van kaıpos in ons teksverse van mekaar te onderskei.

Daar bestaan tans geen ander woordeboek wat hierdie soort informasie (wat berus op insigte van die moderne linguistiek) aan ons bied nie.

STAP 6 - Direk omliggende semantiese velde

Plaas die spesifieke semantiese veld binne die direk omliggende semantiese velde. Kontrasteer die velde met mekaar en probeer ' $n$ beeld vorm van die unieke deel van die werklikheid wat deur hierdie semantiese veld "beteken" word. 
Die linguistiese beginsel dat die kontrastering van verskillende betekenisse binne dieselfde semantiese veld (hier in breëre sin verstaan), tot meer presiese definisies van betekenisse lei, word hier in praktyk gestel. ${ }^{4}$

In die vorige stap het ons vasgestel dat beide semantiese velde 67 en 22 in ons teksverse van toepassing is. In hierdie stap is dit dus nodig om beide hierdie semantiese velde met hulle direk omliggende velde te kontrasteer.

In die spesifieke voorbeeld waarmee ons hier werk, bied hierdie kontrastering van semantiese velde en die inagneming van die hiërargiese ordening daarvan, wel betekenisvolle inligting. Semantiese veld 22 ("Trouble, Hardship, Relief, Favourable Circumstances") word voorafgegaan deur 19 ("Physical impact"), 20 ("Violence, Harm, Destroy, Kill") en 21 ("Danger, Risk, Safe, Save") en dit word gevolg deur 23 ("Physiological Processes and States") en 24 ("Sensory Events and States"). Twee sake kan moontlik uit die kontrastering van hierdie velde afgelei word:

- Die intensiteit van die gebeure volg 'n dalende lyn vanaf 19 na 22 $\star$ Die gebeure van 22 is nie noodwendig spesifiek fisiologiese of sensoriese gebeure of toestande nie.

Die betekenis van кaıpó $\zeta^{\mathrm{d}}$ in Galasièrs $6: 10$ ("ons is in omstandighede") kan dus dui op 'n toestand van 'n laer intensiteit en 'n ander aard as "geweld, skade, vernietig, doodmaak, gevaar, risiko, veilig, geborge." Verder is die "omstandigheid" of "geleentheid" waarvan in Galasiers 6:10 ter sprake is moontlik iets meer algemeen (generies) as spesifiek fisiese of sensoriese gebeure of toestande. Dit sluit egter nie uit dat dit wel fisies en sensories kan wees nie. Hierdie is weer eens een van die beginsels van die moderne linguistiek, naamlik die sogenaamde hiërargiese betekenisverhoudings wat in taal bestaan (Nida, 1979:84vv noem dit "included sets of meaning"'), wat ten grondslag van die woordeboek lê.

Wanneer hierdie inligting in die konteks van Galasiers $6: 10$ van toepassing gemaak word, is dit duidelik dat ons nou oor 'n rykdom linguistiese inligting beskik wat die betekenis van hierdie vers kan opklaar en presiseer. Paulus skryf: "Solank ons die geleentheid het, moet ons aan almal goed doen, veral aan die medegelowiges ..." Ons weet nou baie meer oor die aard van hierdie "geleentheid". Paulus ervaar nie noodwendig sy eie situasie of dié van sy lesers in Galasië as gewelddadig, drukkena', onder gevaar, doodsbedreigend, ens. nie. Dit is nie omstandighede wat gekenmerk word deur 'n hoe intensiteit van gebeurlikhede nie. Dit is " 'n geleentheid" of " 'n situasie" van 'n algemene aard.

Op hierdie stadium, selfs voordat ons nog die spesifieke definisies van kaıpós nagegaan het, kon ons dus reeds uit die bree opset van die woordeboek heelwat waardevolle inligting versamel.

Die kontrastering van semantiese veld 66 met die omliggende semantiese velde lewer nie soveel direk toepasbare inligting op nie. Semantiese veld 66 ("Time") word voorafgegaan deur 64 ("Comparison"), 65 ("Value") en gevolg deur 68 ("Aspect") en 69 ("Affirmation, Nega-

\section{8 - In die Skriflig 1989, 23 (4)}


tion"). Hierdie groep semantiese velde het dus almal met verskillende soorte abstrakte te doen. Abstrakte is 'n kategorie van semantiese woordsoorte wat objekte en gebeure nader kwalifiseer. Die breë semantiese veld wat deur hierdie groep semantiese velde verteenwoordig word, is nadere kwalifikasies van gebeurewoorde.

In Galasiërs $6: 9$ dien kaıpó $\varsigma^{\mathrm{a}}$ b ${ }^{\mathrm{b}}{ }^{\mathrm{c}}$ as kwalifisering van die gebeure

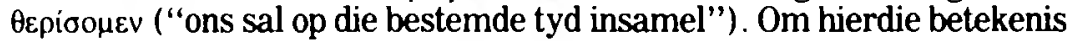
nader te kan kwalifiseer, is dit dus nodig om die volgende stappe in die gebruik van die woordeboek te volg.

\section{STAP 7 - Semantiese veld in sy geheel}

Bestudeer die betrokke semantiese veld se subdomeine soos wat dit aan die begin van die semantiese veld uiteengesit is. Kontrasteer die verskillende subdomeine met mekaar en probeer 'n beeld vorm van die unieke betekenisveld van die subdomein waarin jy geinteresseerd is.

Louw \& Nida (1988 I:xi) motiveer hierdie stap soos volg: "In addition to noting the meanings of lexical items which may immediately precede or follow an individual entry, it is often useful to glance over an entire subdomain. It may also be useful to look at the outline of subdomains which occurs at the beginning of each domain. This will provide a good deal of insight as to the way in which different meanings relate to one another."

Op hierdie stadium is dit dus nou nodig om semantiese veld 67 se subdomeine spesifiek na te gaan. Dit sal ook lig werp op die vraag of ons

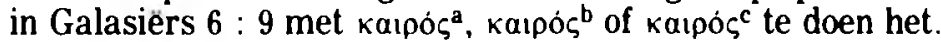

Die woorde en konsepte in die Nuwe Testament wat met "tyd" te doen het, is so omvangryk en ingewikkeld (en dus ook belangrik) dat hele boeke al daaroor geskryf is (vergelyk byvoorbeeld Barr, 1969). Semantiese veld 67 is ook redelik omvattend behandel in die Louw \& Nida-woordeboek. Dit is onderverdeel in tien subdomeine wat binne die hoofkategoriee verdeel is, met 208 betekenisse wat in die semantiese veld as geheel behandel word. Hierdie drie hoofkategoriee is belangrik, naamlik
I Points of Time
(Subdomeine A-D, 67.1-67.77)
II Duration of Time
(Subdomeine E-G, 67.78-67.141)
III Units of Time
(Subdomeine H-J, 67.142-67.208)

Dit is hier weer eens belangrik om die beginsel van die hierargiese ordening van die inskrywings in semantiese velde in gedagte te hou wanneer ons hierdie kategoriee met mekaar kontrasteer. Volgens die samestellers is daar dus 'n beweging van generies na spesifiek vanaf (i) spesifieke punte in die tyd na (ii) tydsduur na (iii) tydseenhede.

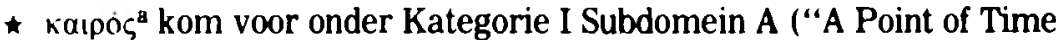
without Reference to Other Points of Time: Time, Occasion Ever, Often" 67.1-67.16). Dit is dus die mees algemene aanduiding vir 'n punt in die tyd wat daar in die Nuwe Testament is. 


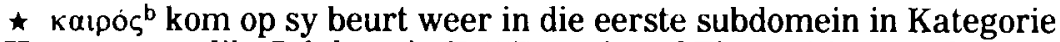
II voor, naamlik, Subdomein E ("Duration of Time without Reference to Points or Units of Time: Time, Spend Time, Always, Eternal, Old, Immediately, Young"). Hierdie betekenismoontlikheid van kaıpo is dus $^{2}$ die mees algemene aanduiding vir 'n tydperk wat daar in die Nuwe Testament is.

$\star \kappa a \iota p o ́ \varsigma^{c}$ kom in die eerste subdomein onder kategorie III voor,

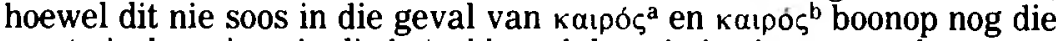
eerste inskrywings in die betrokke subdomein is nie. Kaıpó $\varsigma^{\mathrm{c}}$ kom voor in die Subdomein H ("Indefinite Units of Time: Age, Lifetime, Interval, Period"). Dit is dus onder die groep woorde wat die mees algemene aanduidings vir tydseenhede in die Nuwe Testament is.

Die inligting wat ons tot op hierdie punt versamel het, kan ons nou help om te besluit met watter betekenismoontlikheid van кaıpó $\zeta$ ons in Galasiers $6: 9$ te doen het. Die feit dat dit in hierdie konteks gaan oor "saai en oes" (Gal $6: 7$ - 8) en dat daar in vers 9 sprake is van кaıp $\omega$ i $\delta i \omega$ ("op die bestemde of spesifieke tyd") en $\theta \varepsilon \rho i \sigma o \mu \varepsilon v$ ("oes insamel") laat die indruk dat dit hier oor 'n punt in die tyd gaan. Hierdie keuse is egter nie so voor die hand liggend nie, want "bestemde tyd, naamlik oestyd" kan ook 'n tydsduur veronderstel en verder kan "bestemde tyd, naamlik oestyd" ook dui op 'n bepaalde tydseenheid. Die byvoeglike naamwoord

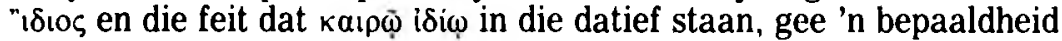
aan die uitdrukking. Die probleem is nou: is dit 'n bepaalde punt in die tyd, ' $n$ bepaalde tydperk of ' $n$ bepaalde tydseenheid?

Die definisies wat in elke geval vir hierdie drie betekenismoontlikhede van кaıрó gegee word, mag ons moontlik help om hier tot 'n gemotiveerde keuse te kom:

Kaıpó ${ }^{a}, \chi \rho o ́ v o \zeta^{b}, \ddot{\omega} \rho \alpha^{a}$ - points of time consisting of occasions for particular events

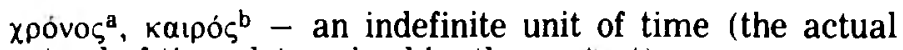
extend of time determined by the context)

$\kappa a\left\llcorner\rho \varsigma^{c}-\right.$ an indefinite period of time, but probably with the implication of the relation of a period to a particular state of affairs.

In die lig van die konteks van Galasiërs $6: 9$ en in die lig van hierdie drie moontlikhede, lyk dit tog of kaıpó $\varsigma^{\mathrm{a}}$ die betekenis is wat hier gebruik is. Die strekking van Galasiers $6: \theta$ is dat die lesers - in hulle huidige omstandighede - nie moeg moet word om goed te doen nie en nie moet verslap nie. Dit veronderstel 'n onbepaalde tyd. Die oes sal

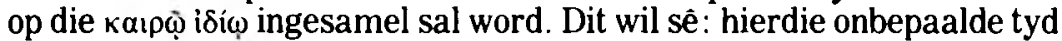
sal wel op ' $n$ bepaalde punt tot ' $n$ einde kom. Die aard van hierdie tyd van oes insameling, naamlik of dit 'n hele periode ("gedurende die oestyd") en of dit 'n tydseenheid ("die hele oestyd") is, is nie in hierdie konteks in fokus nie. Die tweede betekenis, naamlik dié van kaıрó $\varsigma^{b}$ en $\chi \rho$ ovo $^{\mathrm{a}}{ }^{\mathrm{a}}$ word ook deur die konteks uitgesluit omdat die konteks nie die "actual extend of time" aandui soos wat die definisie vereis nie. Daar is slegs sprake van "oes(tyd)", maar presies wánneer hierdie oestyd 
sal wees, word nie aangedui nie. Net so voldoen die konteks ook nie aan die spesifieke vereistes wat vir die betekenis van кaıpó $\varsigma^{\mathrm{c}}$ gestel word nie.

In die lig van die konteks en in die lig van die spesifieke definisies vir hierdie drie betekenismoontlikhede van $\kappa \alpha \iota \rho j \varsigma$, kan ons dus gemotiveerd konkludeer dat кaıрó $\varsigma^{\mathrm{a}}$ in Galasiërs $6: 9$ gebruik word: Paulus moedig sy lesers aan om aan te hou goed doen en belowe hulle dat as hulle nie verslap nie, hulle op 'n bepaalde tydstip wat spesifiek geskik is vir bepaalde gebeure, die oes sal insamel (d.w.s. hulle loon ontvang). Dit is 'n voorlopige definisie van die betekenis van kaıрó in Galasiers 6 : 9.6 Verdere bevestiging vir hierdie konklusie vind ons in die bespreking onder 67.1 waar Markus 13:30 - wat ook oor "oestyd" handel - as illustrasie vir hierdie betekenis gegee word. Dit sou miskien verantwoorde "Skrif-met-Skrif-vergelyking" op woordvlak wees om Galasiers $6: 9$ met Markus $13: 30$ in verband te bring. In beide kontekste word кaıрó $\varsigma^{\mathrm{a}}$ gebruik.?

Let daarop dat ons in die beredenering tot hier hoofsaaklik gewerk het met die verskille in betekenis tussen verskillende betekenisse van dieselfde woord, naamlik kaıpos. Die feit dat hierdie inligting in die woordeboek binne gedefinieerde semantiese velde geklassifiseer is, het dit egter moontlik gemaak om met hierdie mate van presisie en gesofistikeerdheid tot 'n keuse te kom.

Voordat ons tot die volgende stap kan oorgaan, moet ons egter eers die betekenis van kaıpó $\varsigma^{d}$ in semantiese veld 22 in die lig van die semantiese veld as geheel bekyk. Deur semantiese veld 22 in die vorige stap met sy omliggende semantiese velde te kontrasteer, kon ons reeds heelwat waardevolle inligting versamel. Ons kan ons fokus nou meer presies instel. Kaıpó ${ }^{\mathrm{d}}$ kom voor in subdomein G ("Favorable Circumstances or State"). Dit kontrasteer met subdomeine A-D wat handel oor niegunstige gebeure (Trouble, Experience, Cause Trouble, Difficult) en subdomein $\mathrm{E}$ wat handel oor die verligting van nie-gunstige omstandighede (Relief from Trouble). Dit is verder nodig om noukeurig tussen subdomeine F ("Easy, Light") en G ("Favorable Circumstances or State") te onderskei. Beide subdomeine bevat gebeure of toestande wat positief deur die subjek ervaar word. Subdomein $\mathrm{E}$ bevat egter betekenisse wat spesifiek met "maklik" te doen het' en subdomein $F$ bevat betekenisse wat spesifiek gunstig deur die subjek ervaar word. Nie alles wat "maklik" is, is noodwendig "gunstig" nie. Hierdie stelling geld ook omgekeerd: nie alles wat "gunstig" is, is noodwendig "maklik" nie. Daar is dus 'n duidelike kontras tussen hierdie twee semantiese velde.

Met die bespreking van кaıрó $\varsigma^{\mathrm{d}}$ in die vorige stap het ons tot die gevolgtrekking gekom: Paulus ervaar nie sy eie situasie of dié van sy lesers in Galasie as gewelddadig, drukkend, onder gevaar, doodsbedreigend. ens. nie. Dit is nie omstandighede wat gekenmerk word deur 'n hoe intensiteit van gebeurlikhede nie. Dit is "'n geleentheid" of " 'n situasie" van 'n algemene aard. Dit is 'n situasie waarin outeur en lesers in staat is om te kan aanhou goed doen. 
In die lig van die kontrastering van die subdomeine van semantiese veld 22, kan hierdie gevolgtrekking nog nader gekwalifiseer word: dit is spesifiek gunstige omstandighede waarin daar goed gedoen kan word aan ander. Anders gestel: die omstandighede of situasie is gunstig om te kan goed doen. Dit wil egter nie sê dat dit noodwendig maklik sal wees om goed aan ander te doen nie. Aan die ander kant, dit is ook nie dreigende omstandighede van geweld en dood en gevaar van hoe intensiteit nie.

Weer eens het die beginsel van kontrastering van betekenisklusters ' $n$ waardevolle stukkie inligting gebied vir die interpretasie van die betekenis van kaıpós in Galasiërs $6: 10$. Hierdie werkwyse moet deurgaans by die gebruik van die woordeboek gevolg word. Sodoende kan 'n mens waardevolle en veral, verantwoorde, linguistiese inligting versamel wat jou prediking grootliks kan verryk.

Die redenasie in stappe 6 en 7 het myns insiens oortuigend aangetoon dat die waarde van 'n woordeboek wat sy gegewens in semantiese velde aanbied nie beperk is tot die spesifieke direk ter sake semantiese veld alleen nie. Op 'n veel omvattender vlak bied dit waardevolle eksegetiese inligting. Die werkwyse tot dusver het egter deurgaans erns met die konteks van Galasiers 6 gemaak. Semantiese velde is nie een of ander towerformule wat die noukeurige inagneming van die konteks oorbodig maak nie. Juis nie!

\section{STAP 8 - Subdomein}

Bestudeer die betrokke subdomein noukeurig, d.w.s. al die woorde daarbinne, of as dit ' $n$ baie omvattende subdomein is, ten minste die klompie woorde direk voor en direk na die betrokke inskrywing waarin jy belangstel. Kontrasteer die verskille tussen die betekenisse van hierdie verskillende woorde met mekaar ten einde by 'n presiese definisie van die betrokke woord se betekenis uit te kom.

In hierdie finale stap moet ons nou presies dieselfde prosedure van kontrastering met ander direk omliggende linguistiese eenhede volg (soos ons in stappe 6 en 7 gedoen het) om by 'n finale en baie presiese definisie van die woord(e) se betekenis uit te kom.

Die prosedure om die verskille in betekenis tussen verskillende woorde binne dieselfde semantiese veld te kontrasteer, word nou gevolg. Hoewel hierdie beginsel lank reeds in die linguistiek bekend is, maak die beskikbaarheid van die Louw \& Nida-woordeboek dit nou vir die eerste keer vir elke eksegeet moontlik om dit met gemak self prakties te kan doen. Hoe presies 'n mens hierdie kontrastering sal doen, sal uiteraard verskil, afhangende van die aard van die betrokke semantiese veld. Aangesien party semantiese velde baie omvattend is, is die kontrastering van elke betekenis met élke ander betekenis binne die veld 'n baie omvattende proses. Vir die doeleindes van 'n wetenskaplike stuk werk mag dit

\section{2 - In die Skriflig 1989, 23 (4)}


miskien nodig wees om wel so ' $n$ volledige proses te volg en die resultate by wyse van 'n matriks voor te stel. Vir die doeleindes van 'n preek, kan 'n mens waarskynlik volstaan met 'n noukeurige deurlees van die definisies van die direk omliggende inskrywings en 'n paar aantekeninge. Hoe dit ook al sy, deur hierdie kontrastering te doen, benut 'n mens eers die woordeboek op die punt waar dit die mees presiese informasie vir betekenisvasstelling bied.

Ons gee eerstens aandag aan die betekenis van кaı́ó $\varsigma^{\mathrm{d}}$ in Galasiers $6: 10$. In Semantiese veld 22 subdomein G (Favorable Circumstances or State), waarin kaıpós $\zeta^{\mathrm{d}}$ as inskrywing 22.45 voorkom, is daar ook nog

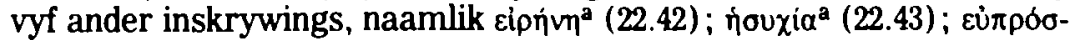

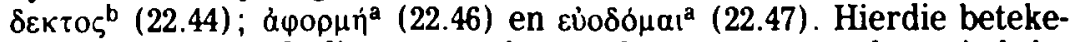
nisse moet nou onderling met mekaar gekontrasteer word ten einde by 'n presiese definisie van kaı́o $\varsigma^{d}$ uit te kom.

Die vernaamste diagnostiese komponente ( = onderskeidende komponente) van die betekenisse binne hierdie betekenisveld kan by wyse van 'n matriks met mekaar gekontrasteer word. Die diagnostiese komponente word vasgestel op grond van die definisies wat van die verskillende betekenisse gegee word.

\begin{tabular}{|c|c|c|c|c|c|c|}
\hline & .42 & .43 & .44 & .45 & .46 & .47 \\
\hline \multicolumn{7}{|l|}{ Komponente } \\
\hline 1. Gunstige omstandighede & $x$ & $x$ & $x$ & $x$ & $x$ & $x$ \\
\hline $\begin{array}{l}\text { Aard van omstandighede: } \\
\text { 2. Vrede en rustigheid } \\
\text { 3. Onversteurde stilte }\end{array}$ & $\begin{array}{l}x \\
x-\end{array}$ & $\begin{array}{l}x- \\
x\end{array}$ & $\begin{array}{l}x-1 \\
x-\end{array}$ & $\begin{array}{l}x- \\
x-\end{array}$ & $\begin{array}{l}x-1 \\
x-\end{array}$ & $\begin{array}{l}x- \\
x-\end{array}$ \\
\hline $\begin{array}{l}\text { Verhouding tot omstandighede: } \\
\text { 4. M.b.t. 'n spesifiek gunstige } \\
\text { geleentheid }\end{array}$ & - & - & $x$ & - & - & - \\
\hline $\begin{array}{l}\text { Potensiaal van omstandighede: } \\
\text { 5. Gunstige geleentheid } \\
\text { 6. Gunstig vir 'n spesifieke } \\
\text { optrede }\end{array}$ & - & - & $\begin{array}{l}- \\
-\end{array}$ & $\begin{array}{l}x \\
x-\end{array}$ & $\begin{array}{l}x \\
x\end{array}$ & - \\
\hline 7. Ervaar/geniet & - & - & - & $x-$ & $x-$ & $x$ \\
\hline
\end{tabular}

Die feit dat daar soveel gevalle is waar die betrokke diagnostiese komponent of aanwesig of afwesig kan wees (gemerk in die matriks met $x-$ ), wys hoe naby aan mekaar hierdie betekenisse gelee is. Die inligting in hierdie matriks kan nou geinterpreteer word om vas te stel watter lig dit op die betekenis van кaıрó $\varsigma^{d}$ in Galasièrs $6: 10$ werp. Anders as

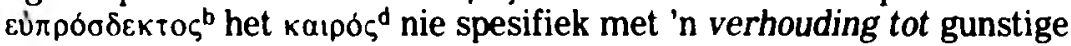


omstandighede te doen nie. Dit gaan meer oor die aard van die omstandighede self. Dit is moontlik dat hierdie omstandighede gekenmerk kan word deur vrede en rustigheid en onversteurde stilte (diagnostiese komponente 2 en 3), maar dit hoef ook nie die geval te wees nie. Die feit dat hierdie betekeniskomponente wel in hierdie semantiese veld voorkom, maak dit miskien verantwoord om dit versigtig en ná kontrole met die konteks van Galasiërs $6: 10$, in berekening te bring by die verklaring van die betekenis van $\kappa a \iota \rho \varsigma^{\mathrm{d}}$ in Galasiërs $6: 10$. Diagnostiese komponente 5 en 6 is in die lig van die konteks van Galasiërs 6 waarskynlik meer direk van toepassing: dit is gunstige omstandighede wat besondere potensiaal het, of selfs gunstig vir 'n spesifieke optrede kan wees. Ook dit moet egter aan die konteks getoets word.

As finale gevolgtrekking oor die betekenis van кaıpó in Galasièrs $6: 10$, moet ons nou ál ons vorige resultate met die resultate van hierdie laaste stap integreer en tot 'n finale sintese kom. Miskien kan 'n mens dit so formuleer:

Paulus ervaar nie noodwendig sy eie situasie of dié van sy lesers in Galasië as gewelddadig, drukkend, onder gevaar, doodsbedreigend, ens. nie. Dit is nie omstandighede wat gekenmerk word deur 'n hoe intensiteit van gebeurlikhede nie. Dit is " 'n geleentheid" of " 'n situasie" van 'n algemene aard. Tog is dit spesifiek gunstige omstandighede waarin daar goed gedoen kan word aan ander. Dit wil egter nie sé dat dit noodwendig maklik sal wees om goed aan ander te doen nie - al is dit nie dreigende omstandighede van geweld en dood en gevaar van hoe intensiteit nie. Dit is 'n situasie wat moontlik gekenmerk word deur rustigheid en stilte. Veral is dit 'n situasie wat die potensiaal inhou dat die lesers van die brief sekere dinge kan doen. In die konteks self word hierdie "dinge" waarvoor die situasie die potensiaal het, gespesifiseer (maar nie gepresiseer nie): Hou aan goed doen. ${ }^{9}$

Ons gee vervolgens aandag aan die betekenis van кaıpó $\varsigma^{\mathrm{a}}$ in Galasiërs $6: 9$. In semantiese veld 67 subdomein $A$, waarin hierdie betekenis voorkom, is daar in totaal 16 betekenisse ingeskryf. Hierdie betekenisse moet nou met die betekenis van $\kappa a \iota \rho o ́ \varsigma^{\mathrm{a}}, \chi \rho \delta \delta^{\circ} \zeta^{\mathrm{b}}, \tilde{\omega} \rho \alpha^{\mathrm{a}}(67.1)$ gekontrasteer word. Aangesien dit ' $n$ redelik omvattende subdomein is, sal dit te uitvoerig raak om elke betekenis met elke ander een te kontrasteer. 'n Mens is dus genoodsaak om van 'n matriks gebruik te maak indien jy die kontrastering in groot detail wil doen. Vir die doeleindes van hierdie illustrasie word nie nou weer 'n matriks saamgestel nie, maar volstaan ek met enkele aantekeninge wat uit hierdie betekenisveld versamel is.

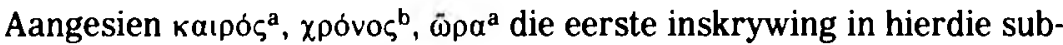
domein is, het dit die mees algemene betekenis. Volgens die definisie van hierdie betekenis staan die tyd as spesifieke punt in fokus: 'n punt in die tyd wat bestaan uit 'n geleentheid vir spesifieke gebeurtenisse. I looteouia in 67.2 is ook 'n punt in die tyd, maar meer spesifiek 'n punt wat reeds by voorbaat gekies is. In 67.3 beteken wpaio $\zeta^{b}$ ' $n$ punt in die tyd wat besonderlik gepas is. In 67.4 is die fokus van die betekenis van ruк арєи) 
ander tyd deur die subjek. In 67.5 word die betekenis van eủкaıria gedefinieer as ' $n$ gunstige geleentheid vir een of ander gebeurtenis' en

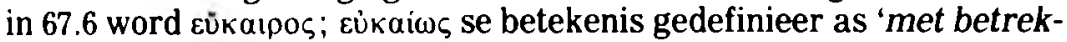
king tot 'n gunstige geleentheid vir een of ander gebeurtenis'. Betekenis-

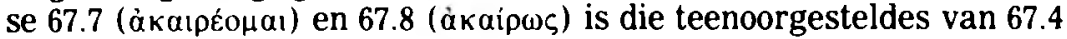
en 67.6. Dit is terloops een van die opvallende kenmerke van die beginsel van semantiese velde dat teenoorgestelde betekenisse saam gegroepeer word. Ook 67.9 en 67.10 bevat teenoorgestelde betekenisse.

Op hierdie wyse kan 'n mens aangaan om die betekenisse te kontrasteer en die spesifieke fokus van die verskillende betekenisse te probeer vasstel. In hierdie bespreking is hierdie spesifieke fokusse (of diagnostiese komponente) telkens gekursiveer. Teen die agtergrond van die beginsel

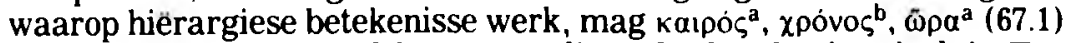
moontlik die spesifieke fokusse van die ander betekenisse insluit. Tog moet so iets telkens eers versigtig aan die konteks getoets word aangesien die generies-spesifieke ordening van die semantiese velde nie noodwendig beteken dat dit die betekenisse in presiese hierargiese betekenisklusters inpas nie. Of die каıрó $\varsigma$ van Galasiers $6: 9$ dus inhou dat dit ' $n$ tyd is wat reeds by voorbaat gekies is en/of besonderlik gepas is (die fokusse van ander betekenisse in hierdie semantiese veld), moet 'n mens dus aan die konteks toets. Dit lyk of daar in hierdie konteks juis gekies moet word vir die algemeenheid van die betekenis van кaıó $\varsigma^{a}$ : "Laat ons dan nie moeg word om goed te doen nie, want op die bestemde tyd sal ons die oes insamel as ons nie verslap nie." Hierdie "bestemde/regte tyd" veronderstel heel moontlik dat dit 'n tyd is wat vooraf gekies is, wat spesifiek gunstig en gepas is vir die oes, ens. (d.w.s. die ander meer spesifieke betekenisse in hierdie betekenisveld). Indien een van die ander woorde in hierdie semantiese veld hier gebruik is, sou daardie woord se spesifieke fokus van die tydsaanduiding in hierdie vers gepresiseer het en die algemeenheid uitgeskakel het. En juis dit wil die konteks klaarblyklik nié doen nie. Die presiese aard van die tyd waarop geoes sal word, is nie hier in fokus nie, maar wel die feit dát daar op ' $n$ bestemde tydstip geoes sal word.

Wanneer ons dus tot 'n sintese moet kom oor die betekenis van kaıpó in Galasiers $6: 9$, moet ons die resultate van al die vorige stappe integreer met die afleidings wat ons so pas uit dic kontrastering van betekenisse in die spesifieke semantiese veld gemaak het. Miskien kan 'n mens dit so formuleer:

Paulus skryf vir sy lesers dat hulle moet aanhou goed doen. As hulle nie verslap nie, sal hulle op die bestemde/regte tyd hulle loon ontvang. 'n Abstrak (кaıpó) word gebruik om die gebeurewoord "ons sal die oes insamel" te kwalifiseer. Die lesers - in hulle huidige omstandighede - moet nie moeg word om goed te doen nie. Dit veronderstel dat hulle tyd tot hulle beskikking het om te

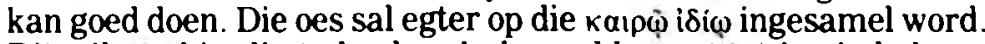
Dit wil sê: hierdie tyd sal op 'n bepaalde punt tot 'n einde kom. Die aard van hierdie tyd van oes insameling, naamlik of dit ' $n$ hele periode ("gedurende die oestyd") is en of dit 'n tydseenheid ("die 
hele oestyd") is, is nie in hierdie konteks in fokus nie. Wat in fokus is, is dat daar op 'n bepaalde punt in die tyd 'n einde aan hierdie tyd vir goed doen sal kom. Hierdie punt in die tyd is spesifiek geskik vir die bepaalde gebeure, (nl. om die oes in te samel). Dit is ook waarskynlik 'n tyd wat vooraf bestem is.

2.2 Sinopsis van die agt stappe

1) Soek die Griekse woord in die indeks in Volume 2 op.

2) Interpreteer die gegewens wat die indeks bied, naamlik (i) in hoeveel en (ii) in watter semantiese velde die woord voorkom, en (iii) of jy in hierdie spesifieke geval nie moontlik met 'n idiomatiese uitdrukking waarin die woord voorkom, te doen het nie.

3) Besluit watter betekenismoontlikheid of betekenismoontlikhede die waarskynlikste van toepassing is in die konteks wat jy bestudeer.

4) Soek die betrokke verwysing na die toepaslike semantiese veld en subdomein waarop jy in stap 3 besluit het, in Vol 1 van die woordeboek op.

5) Plaas die semantiese veld binne die geheelkonteks van die semantiese velde soos wat dit in Vol 1 geklassifiseer is. Dit wil sê, plaas dit in terme van (i) unieke referente, (ii) klasreferente en (iii) merkers; of meer spesifiek, objekte (semantiese velde 1-12), gebeure (semantiese velde 13-57), abstrakte (semantiese velde 58-91), eiename en plekname (semantiese veld 93), verhoudingswoorde (semantiese velde 89), en diskoersmerkers (semantiese velde 91 en 92).

6) Plaas die spesifieke semantiese veld binne die direk omliggende semantiese velde. Kontrasteer die velde met mekaar en probeer 'n beeld vorm van die unieke deel van die werklikheid wat deur hierdie semantiese veld "be-teken" word.

7) Bestudeer die betrokke semantiese veld se subdomeine soos wat dit aan die begin van die semantiese veld uiteengesit is. Kontrasteer die verskillende subdomeine met mekaar en probeer ' $n$ beeld vorm van die unieke betekenisveld van die subdomein waarin jy geïnteresseerd is.

8) Bestudeer die betrokke subdomein noukeurig, dit wil sê al die woorde daarbinne, of, as dit ' $n$ baie omvattende subdomein is, ten minste die klompie woorde direk voor en direk na die betrokke inskrywing waarin jy belangstel. Kontrasteer die verskille tussen die betekenisse van hierdie verskillende woorde met mekaar ten einde by 'n presiese definisie van die betrokke woord se betekenis uit te kom.

\section{DIE GEBRUIK VAN DIE ANDER TWEE INDEKSE}

Die verskil tussen die gebruik van Engels-Griekse indeks en GrieksEngelse indeks (wat so pas breedvoerig behandel is), is hoofsaaklik 'n verskil in die beginpunt van die ondersoek. In plaas van om met 'n Griekse woord te begin, bied hierdie indeks aan 'n mens die geleentheid om met 'n Engelse woord as uitgangspunt jou soektog deur die woordeboek te begin. So byvoorbeeld dui die indeks onder die inskrywing "occasion" die volgende inskrywings aan: $22.45,46 ; 67.16$ (Louw \& Nida, 1988 II :307), en onder die inskrywing "time" die volgende inskrywings: 67.1$208 ; 85.79$ (Louw \& Nida, 1988 II:327). Behalwe vir semantiese veld 85 (wat 
nie in die konteks van Gal $6: 9$ - 10) van toepassing is nie, lei hierdie indeks ons dus direk na semantiese velde 22 en 67 wat ons reeds in die vorige afdeling bespreek het. Sodra 'n mens op hierdie wyse die toepaslike semantiese velde geidentifiseer het, bly die prosedure van verskillende stadia van kontrastering (soos in \$2 geillustreer) dieselfde.

Dit gebeur dikwels dat ' $n$ mens inligting oor ' $n$ bepaalde onderwerp of begrip in die Nuwe Testament wil versamel, sonder dat jy weet watter Griekse woord(e) daarvoor gebruik word. In so 'n geval is hierdie indeks uiters waardevol. Iemand wat oor geen of baie min kennis van Grieks beskik, word ook deur hierdie indeks in staat gestel om leksikale inligting te versamel. Die katkisasie-onderwyser of die Bybelkunde-onderwyser wat 'n les oor Galasiërs $6: 9$ - 10 wil voorberei, kan dus aan die hand van hierdie indeks (beginnende met die woorde in Engelse vertalings) maklik by die toepaslike semantiese velde uitkom en sodoende waardevolle inligting bekom.

Ook in die geval van die gebruik van die indeks van Skrifverwysings, is dit hoofsaaklik die invalshoek of beginpunt wat verskil. Sodra 'n mens aan die hand van hierdie indeks die semantiese velde waarin jy belangstel, geidentifiseer het, bly die proses van verskillende stadia van kontrastering dieselfde. In die geval van Galasiërs $6: 9-10$ verwys die

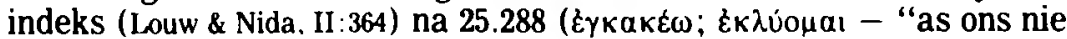
verslap/laat los nie, sal ons op die regte tyd die oes insamel") en 90.58 ( $\pi \rho \varsigma^{\mathrm{e}}{ }^{-}$"laat ons goed doen aan almal"). Nie een van hierdie verwysings handel dus spesifiek oor die woord kaıpó nie. Dit is so omdat hierdie indeks van teksverwysings slegs verwysings na die plekke in die woordeboek bevat waar hierdie spesifieke tekste as illustrasies gebruik is. Dit is dus nie 'n volledige indeks wat alle teksverwysings na álle Griekse woorde bevat nie. So 'n indeks sou onmoontlik lywig en waarskynlik ook nie baie prakties gewees het nie. Al bied hierdie indeks dus nie ' $n$ invalshoek om spesifiek die betekenis van kaıpós in Galasiers $6: 9$ - 10 na te gaan nie, lei dit ons tog na ander plekke in die woordeboek waar ons waardevolle inligting oor ons teksverse kan versamel. Dit sal dus die moeite loon om altyd hierdie indeks te raadpleeg oor die woorde in die teksverse waaroor ' $n$ mens besig is om 'n preek te maak.

\section{TEN SLOTTE}

Met die twee redelik omvangryke beskrywings van die betekenisse van каıрó 's in Galasiërs $6: 9$ - 10 (aan die einde van \$2) het ons aan die einde van 'n lang proses van versameling en kontrastering gekom. Daaruit blyk duidelik watter groot hoeveelheid informasie 'n mens op linguistiesverantwoorde basis uit die Louw \& Nida-woordeboek kan versamel. Dit is ook duidelik hoe ingrypend die verskil in betekenis kan wees waarvoor dieselfde woord in twee direk opeenvolgende verse gebruik word. Uiteraard moet hierdie resultate getoets word aan die hand van historiese en literére navorsing (sake wat gewoonlik in goeie kommentare aan die orde kom). Die Louw-Nida woordeboek is in die eerste plek gerig op linguistiese data. Hoewel die optimale benutting daarvan aan ons 'n magdom eksegetiese inligting verskaf, sou dit ' $n$ fout wees om te meen dat alle tersaaklike eksegetiese inligting slegs deur die gebruik van hier- 
die woordeboek versamel kan word.

Op grond van hierdie resultate is dit miskien nou ook meer verstaanbaar waarom 'n mens moet waak teen "illegitimate totality transfer" (vergelyk $\$ 2.5$ in vorige artikel). Al die verskillende betekenismoontlikhede van kalpós kan nie in elke konteks waar die woord gebruik word, ingedra word nie. As ons dit in hierdie geval sou doen, ignoreer ons of oorlaai ons die verskil tussen die betekenisse van kaıpós in Galasiërs $6: 9$ en Galasiërs $6: 10$. Daarom moet 'n mens uiters versigtig wees om die sogenoemde "Skrif-met-Skrif-vergelyking" as eksegetiese prosedure op woordvlak te gebruik. 'n Mens sou miskien al die kontekste waarin кaıpo $\zeta^{\mathrm{a}}$ voorkom, met al die ander kontekste waarin кaıpó $\varsigma^{\mathrm{a}}$ voorkom

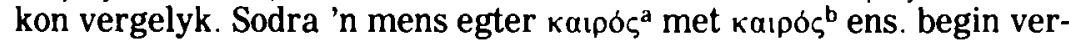
gelyk, kom daar 'n hele stel linguistiese beginsels in gedrang en moet dit ons tot groot versigtigheid noop. 'n Mens kan dus ook nie maar net met 'n konkordansie in die hand al die plekke waarin 'n bepaalde woord voorkom met mekaar vergelyk en al die verskillende betekenisse "bymekaar tel" en dink jy het sodoende die sogenaamde "diepte" van die Bybelse woord "ontgin" nie. Ons moet dus ook versigtig wees met 'n veralgemenende stelling soos: "In die Nuwe Testament beteken die woord kaıpós...". So 'n stelling moet telkens in meer as een opsig gekwalifiseer word.

Die Louw \& Nida-woordeboek bied egter nou aan ons die positiewe moontlikheid om nie net hierdie tipe slaggate te vermy nie, maar ook om 'n skat van waardevolle eksegetiese inligting maklik te bekom.

\section{LITERATUUR}

Barr, J. 1961. The semantics of biblical language. Oxford: University Press. 1969. Biblical words for time. Naperville: Allenson.

Botha, J. [1990]. Semeion. Inleiding tot aspekte van die interpretasie van die Griekse Nuwe Testament. Pretoria: NG Kerkboekhandel.

Deist, FE. 1988. Eksegese as "leeskompetensie": Oor onderrig in Skrifuitleg. NGTT $30: 56-63$.

Lategan. BC. 1986. Die Brief aan die Galasiers. Kaapstad: NG Kerk-Uitgewers.

Louw, JP. 1982. Semantics of New Testament Greek. Philadelphia: Fortress. (red) 1985. Lexicography and translation. With special reference to Bible translation. Kaapstad: Bybelgenootskap van Suid-Afrika

\& Nida, EA. 1988. Greek-English lexicon of the New Testament based on semantic domains. (2 vols). New York: UBS.

Nida. EA. 1979. Componential analysis of meaning. An introduction to semantic structures. Den Haag: Mouton.

Silva, M. 1983. Biblical words and their meaning. An introduction to lexical semantics. Grand Rapids: Zondervan.

\section{VOETNOTE}

1. Verwerking van 'n lesing gelewer op 14 Augustus 1989 tydens die Werkgemeenskap van Teologiese Studente aan die Teologiese Skool op Potchefstroom

2. Aangesien die hele etiese gedeelte van die Galasiersbrief (vanaf $5: 13$ ) in hierdie verse saamgevat word (Lategan 1986:113), kan daar 'n goeie saak daarvoor uitgemaak word om hierdie verse as teksverse te neem

3. Let op die baie belangrike feit dat hierdie idioom in ander semantiese velde (65 en 68) voorkom as die woord каוpos ( $67 \mathrm{en} 22$ ). Dit bevestig die linguistiese beginsel dat woorde in idiomatiese uitdrukkings nuwe betekenisse aanneem. Om byvoorbeeld die Afrikaanse uitdrukking "lepel in die dak steek" te verstaan, help dit jou niks 
om die woord "lepel" binne die semantiese veld "eetgerei" te verstaan nie - so kom jy nooit by die betekenis van die idioom uit nie. Net so kom die idioom "A

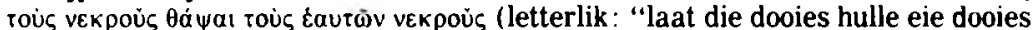
begrawe") (Luk 9:60) nie in die semantiese veld 23 ("Physiological Processes and States") subdomein G ("Live, Die") voor nie, maar wel in semantiese veld 33 ("Communication") subdomein J ("Interpret, Mean, Explain"). Die idioom beteken: "die saak waaroor dit hier gaan is nie die werklike punt nie."

4. Hier mag die ordeningsbeginsel dat semantiese velde so ver moontlik vanaf mees generiese na mees spesifieke betekenisse georden is (Louw \& Nida 1988 I : xix), soms waardevolle inligting bied. Die mees generiese gebeure-woorde vind ons dus in semantiese veld 13: "Be, Become, Exist, Happen" en die mees spesifieke gebeure woorde in semantiese veld 57 "Possess, Transler, Exchange". Louw \& Nida (1988:vi) waarsku egter tereg dat betekenisklusters in 'n taal hulle nie altyd uitleen vir hierdie presies logiese soort klassifisering nie. Daarom beklemtoon ek dit dat hierdie indelingsbeginsel net soms betekenisvolle inligting kan bied. In die geval van die ordening binne 'n spesifieke semantiese veld, bied hierdie indelingsbeginsel oor die algemeen meer direk betekenisvolle informasie.

5. Op grond van die verskynsel van insluitende (of hierargiese) betekenisse kan taksonomiee opgestel word. byvoorbeeld: alle pofadders is slange, alle slange is reptiele en alle reptiele is diere. Omgekeerd werk hierdie beginsel egter nie: alle diere is nie reptiele nie, ens. Die mees generiese betekenis in hierdie kluster is dus "dier" en die mees spesifieke is "pofadder". Deur in gedagte te hou dat semantiese velde in die woordeboek so ver moontlik generies-spesifiek georden is, kan 'n mens dikwels - soos in hierdie geval met кaıos - belangrike afleidings oor woordbetekenisse maak.

6. Die woord mag wel in hierdie konteks moontlik verwys na die wederkoms. maar kaıpós beteken nié hier "wederkoms" nie. Die onderskeid tussen betekenis en verwysing moet altyd deeglik in gedagte gehou word (vergelyk Botha [1990]:136-139) - dit is juis een van die aspekte waarin die meeste ander woordeboeke mank gaan

7. Vergelyk verder $\$ 4$ van hierdie artikel oor die implikasies van die Louw \& Nidawoordeboek vir die gebruik van die sogenoemde "Skrif-met-Skrif-vergelyking" as eksegetiese praktyk.

8. Maklik om te verduur, maklik in die sin dat dit nie groot werk of moeite verg nie, maklik of aangenaam met die implikasie van gepastheid en dit wat sonder moeilikheid verrig kan word.

9. "Goed doen" is immers 'n baie omvattende begrip 